\title{
S13 Fig
}
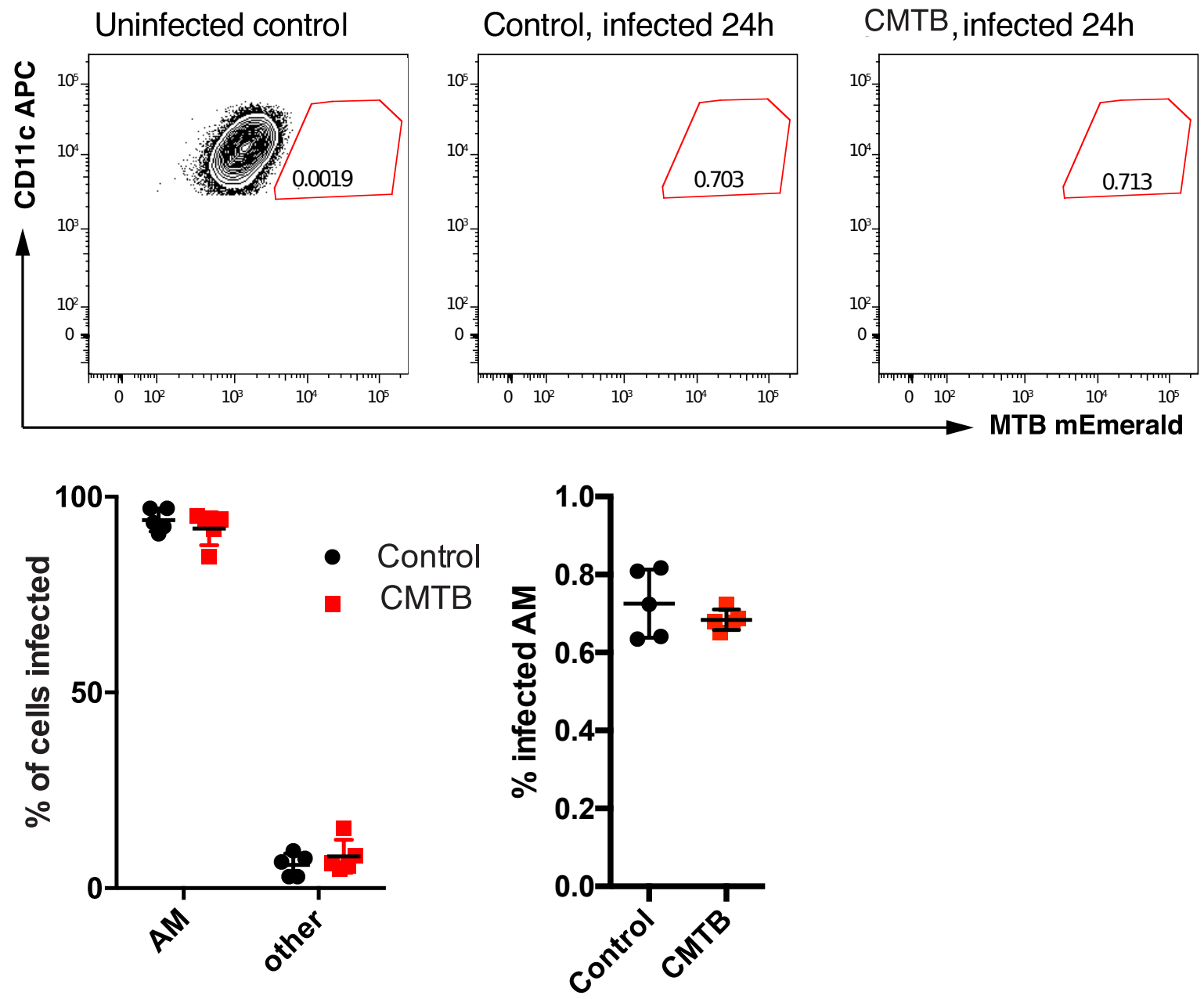